\title{
Adaptability and stability of common bean genotypes in family farming systems
}

\author{
Patrícia Guimarães Santos Melo(1), Renata Cristina Alvares(2), Helton Santos Pereira(3), \\ Antônio Joaquim Braga Pereira Braz ${ }^{(4)}$, Luis Claudio Faria ${ }^{(3)}$ and Leonardo Cunha Melo(3)
}

\begin{abstract}
(1)Universidade Federal de Goiás, Campus Samambaia, Avenida Esperança, s/no, Chácara de Recreio Samambaia, CEP 74690-900 Goiânia, GO, Brazil. E-mail: pgsantos@gmail.com ${ }^{(2)}$ Caraíba Melhoramento de Sementes, Rodovia GO-174, Km 4,9, s/no, Fazenda Lagoinha, CEP 75908-570 Rio Verde, GO, Brazil. E-mail: renataalvares08@hotmail.com ${ }^{(3)}$ Embrapa Arroz e Feijão, Rodovia GO-462, Km 12, Fazenda Capivara, Zona Rural, Caixa Postal 179, CEP 75375-000 Santo Antônio de Goiás, GO, Brazil. E-mail: helton.pereira@embrapa.br, luis.faria@embrapa.br, leonardo.melo@embrapa.br ${ }^{(4)}$ Universidade de Rio Verde, Campus Rio Verde, Fazenda Fontes do Saber, Caixa Postal 104, CEP 75901-970 Rio Verde, GO, Brazil. E-mail: braz@unirv.edu.br
\end{abstract}

Abstract - The objective of this work was to evaluate the interaction between genotypes and environments for grain yield of common bean (Phaseolus vulgaris) lines and cultivars with potential for use in family farming systems. Data from value for cultivation and use tests, carried out in 20 environments in the state of Goiás, Brazil, were analyzed in two cycles (2007/2008 and 2009/2010) in the dry, rainy, and winter crop seasons. Each test consisted of 15 genotypes from the carioca, purple, and rosinha common bean commercial groups. The experimental design was randomized complete block, with three replicates. The methodologies used to test the stability and adaptability of the genotypes were the one of Lin \& Binns, of Cruz, the additive main effects and multiplicative interaction model (AMMI) to calculate the weighted average of absolute scores and productivity (WAASP), and the GGE biplot graphical analysis. The productive performance of the common bean lines and cultivars is affected by genotype $\mathrm{x}$ environment interaction. The methodologies adopted allow the selection of cultivars for cropping, and of cultivars and lines for use as parents in order to obtain segregating populations for selection in a family farming system.

Index terms: Phaseolus vulgaris, AMMI, cultivars, genotype x environment interaction, GGE biplot analysis, value for cultivation and use.

\section{Adaptabilidade e estabilidade de genótipos de feijoeiro-comum em sistema de agricultura familiar}

Resumo - O objetivo deste trabalho foi avaliar a interação de genótipos com ambientes para produtividade de grãos de linhagens e cultivares de feijoeiro-comum (Phaseolus vulgaris) com potencial de uso em sistema de agricultura familiar. Foram analisados os dados dos ensaios de valor de cultivo e uso conduzidos em 20 ambientes do Estado de Goiás, em dois ciclos (2007/2008 e 2009/2010), nas safras da seca, das águas e de inverno. Cada ensaio foi constituído por 15 genótipos de feijoeiro-comum dos grupos comerciais carioca, roxo e rosinha. Utilizou-se o delineamento em blocos completos ao acaso com três repetições. As metodologias utilizadas para o estudo de estabilidade e adaptabilidade foram a de Lin \& Binns, a de Cruz, o modelo de efeitos aditivos principais com interação multiplicativa (AMMI) para cálculo da média ponderada de escores absolutos e produtividade (MPEAP), e a análise gráfica GGE biplot. O desempenho produtivo das linhagens e das cultivares de feijoeiro-comum é influenciado pela interação de genótipos com ambientes. As metodologias empregadas permitem selecionar cultivares para cultivo, e cultivares e linhagens como genitores com o objetivo de obter populações segregantes para seleção em sistema de agricultura familiar.

Termos para indexação: Phaseolus vulgaris, AMMI, cultivares, interação genótipo x ambiente, análise GGE biplot, valor de cultivo e uso.

\section{Introduction}

Brazil stands out as one of the world's largest producer and consumer of common bean (Phaseolus vulgaris L.), with an average productivity of approximately $1,400 \mathrm{~kg}$ $\mathrm{ha}^{-1}$ when considering the three recommended sowing seasons (Silva \& Wander, 2013). These seasons - rainy, dry, and winter - are responsible for 41.7, 36.7, and $21.6 \%$ of total production, respectively (Torga et al., 2013b; Feijão, 2016), supplying the domestic market all year round. 
Common bean is grown at different seasons of the year and sites, in subsistence to high-tech farming areas. In family farms, it is considered an economic alternative and, therefore, is a common activity; however, the cropped area can still be expanded since only less than 50 hectares are planted with the crop in $99.08 \%$ of the farms, 50 to 200 hectares in $0.77 \%$, and over 200 hectares just in $0.15 \%$ (Silva \& Wander, 2013).

A marked interaction between genotypes and environments is also expected for this crop, particularly regarding grain yield, whose importance has been evidenced in several studies (Oliveira et al., 2006; Melo et al., 2007; Pereira et al., 2009b, 2012; Torga et al., 2013b). However, there are no consistent reports in the literature for the specific conditions of the family farming system, because common bean breeding programs focus on genotypes with an extensive range of adaptation (Torga et al., 2013a; Pereira et al., 2016).

Aiming to minimize the effects of the interaction between genotypes and environments, in general, genetic breeding programs select materials with wide adaptation and stability, and, therefore, recommended for several sites (Malosetti et al., 2013). In the case of the family farming system, it is necessary to identify materials that are stable and adapted to the specific environments used by the farmers (Bucheyeki \& Mmbaga, 2013), since these cultivars show many advantages, such as: high yield, greater efficiency in the use of soil nutrients, resistance to pests and diseases, and tolerance to environmental stresses.

In this sense, participatory research methods with genetic improvement are important and promising because they not only promote the development of improved cultivars but also allow working with the entire community, as well as with researchers from different areas, consultants, and farmers associations. In addition, a larger number of environments are tested in these methods and different information is manipulated compared with conventional breeding (Desclaux et al., 2008).

The objective of this work was to evaluate the interaction between genotypes and environments for grain yield of common bean lines and cultivars with potential for use in family farming systems.

\section{Materials and Methods}

Value for cultivation and use (VCU) testing of common bean was conducted in 20 representative environments in the state of Goiás, Brazil, during four years (2007 to 2010) in the dry, rainy, and winter crop seasons. Each trial consisted of 15 common bean lines developed by Embrapa Arroz e Feijão: 7 from the carioca commercial group (CNFC 10713, CNFC 10721, CNFC 10729, CNFC 10733, CNFC 10753, CNFC 10757, and CNFC 10758), 2 from the purple group (CNFRX 11996 and CNFRX 10241), 1 from the rose group (CNFRS 11997), and 5 controls (BRS Cometa, BRS Pontal, BRS Requinte, BRS Pitanga, and BRS Vereda). The experiment was carried out in a randomized complete block design, with three replicates, in plots with four 4-m long lines. Grain yield data were collect in the two central lines.

Of the trials, 7 were carried out in farmer properties in the municipalities of Rubiataba, Ipiranga, and Nova Veneza in the state of Goiás, whereas 13 were conducted at the experimental stations of Embrapa Arroz e Feijão and Empresa de Assistência Técnica e Extensão Rural do Estado de Goiás. At the stations, the management was similar to that adopted by the farmers: half of the recommended fertilization and side dressing rates, i.e., $400 \mathrm{~kg} \mathrm{~N}-\mathrm{P}_{2} \mathrm{O}_{5}-\mathrm{K}_{2} \mathrm{O}$ and two side dressing fertilizations of $20 \mathrm{~kg} \mathrm{~N}$, respectively. No chemical control of pests and diseases was carried out.

Grain yield data were subjected to the joint analysis of variance, considering the effect of genotypes as fixed and of environments as random. To evaluate experimental quality, the statistics selective accuracy (SA) and F-test value of the individual analyzes were also used, according to Resende \& Duarte (2007). The coefficient of determination $\left(\mathrm{R}^{2}\right)$ was estimated by the expression $\mathrm{R}_{\mathrm{i}}{ }=\mathrm{SS}_{\mathrm{i}} / \mathrm{SS}_{\mathrm{t}}$, where $\mathrm{SS}_{\mathrm{i}}$ is the sum of squares of the source of variation $i$ and $\mathrm{SS}_{\mathrm{t}}$ is the total sum of squares.

The adaptability and stability parameters of the lines were estimated by the methods of: Lin \& Binns (1988) modified by Oliveira et al. (2006); Cruz et al. (1989); the additive main effects and multiplicative interaction (AMMI) model (Duarte \& Vencovsky, 1999) with adaptations for the calculation of the weighted average of absolute scores (WAAS) (Pereira et al., 2009a) and of the weighted average of absolute scores and productivity (WAASP) (Torga et al., 2016); and genotype main effect plus genotype-by-environment interaction (GGE) biplot graphical analysis (Yan, 2002; Yan \& Tinker, 2005). The genotypes were ranked by the WAAS values, and the lowest was considered the 
most stable (Pereira et al., 2009a). A weight equal to three and to two was used for WAASP and WAAS, respectively (Pontes Júnior et al., 2016; Torga et al., 2016), allowing the assessment of adaptability and stability simultaneously; the yield and WAAS data were transformed to the same scale.

To graphically represent the effect of the genotype $x$ environment interaction, a GGE biplot graph was built with the main components 1 and 2 of the AMMI analysis, according to Yan (2001), in order to group the sites into mega-environments and to facilitate the selection of superior genotypes.

\section{Results and Discussion}

The average grain yield differed between environments, with values up to approximately ten times greater, ranging from $276 \mathrm{~kg} \mathrm{ha}^{-1}$ in Nova Veneza, during the rainy season, in 2007 , to 2,841 $\mathrm{kg} \mathrm{ha}^{-1}$ in Anápolis, also during the rainy season, in 2009 (Table 1). The performance of the genotypes was affected by variations in the different environments altitude, for example, varied from 448 to $1,036 \mathrm{~m}-$, as well as by years and seasons. For this reason, common bean cultivars must show stability in order to be competitive in contrasting environmental conditions (Pereira et al., 2016). Whenever possible, farmers try to control the environment in order to maximize the productive potential of cultivars, but when they do not have the economic conditions to do this, they probably will have to rely on the stability and adaptability of the cultivars to the cropping site. Therefore, the effect of genotype $\mathrm{x}$ environment interaction may be more drastic when farmers do not have the technologies to

Table 1. Geographic sites and summaries of the individual analysis of variance for grain yield of common bean (Phaseolus vulgaris) lines and cultivars evaluated in 20 trials in the dry, rainy, and winter crop seasons in the state of Goiás, Brazil, from 2007 to 2010 .

\begin{tabular}{|c|c|c|c|c|c|c|c|c|}
\hline Site (municipality) & Altitude (m) & Latitude (S) & Longitude (W) & $\mathrm{MS}_{\mathrm{g}}$ & $\mathrm{MS}_{\mathrm{e}}$ & Yield $\left(\mathrm{kg} \mathrm{ha}^{-1}\right)$ & CV (\%) & SA \\
\hline & \multicolumn{8}{|c|}{ Dry season in 2007} \\
\hline \multirow[t]{2}{*}{ 1. Santo Antônio de Goiás } & 823 & $16^{\circ} 29^{\prime}$ & $49^{\circ} 18^{\prime}$ & 14,162 & $8,910^{\text {ns }}$ & 691 & 13.7 & 0.61 \\
\hline & \multicolumn{8}{|c|}{ Winter in 2007} \\
\hline \multirow[t]{2}{*}{ 2. Itumbiara } & 448 & $18^{\circ} 25^{\prime}$ & $49^{\circ} 12^{\prime}$ & 33,448 & $11,381 * *$ & 510 & 20.9 & 0.81 \\
\hline & \multicolumn{8}{|c|}{ Rainy season in 2007} \\
\hline 3. Rubiataba & 632 & $15^{\circ} 09^{\prime}$ & $49^{\circ} 48^{\prime}$ & 29,517 & $14,196^{*}$ & 843 & 14.1 & 0.72 \\
\hline 4. Anápolis & 1,017 & $16^{\circ} 19^{\prime}$ & $48^{\circ} 57^{\prime}$ & 47,700 & $8,099 * *$ & 619 & 14.5 & 0.91 \\
\hline 5. Santo Antônio de Goiás & 823 & $16^{\circ} 29^{\prime}$ & $49^{\circ} 18^{\prime}$ & 68,971 & $7,150^{* *}$ & 655 & 12.9 & 0.95 \\
\hline \multirow[t]{2}{*}{ 6. Nova Veneza } & 806 & $16^{\circ} 22^{\prime}$ & $49^{\circ} 19^{\prime}$ & 15,604 & $4,338^{* *}$ & 276 & 23.8 & 0.85 \\
\hline & \multicolumn{8}{|c|}{ Rainy season in 2008} \\
\hline 7. Anápolis & 1,017 & $16^{\circ} 19^{\prime}$ & $48^{\circ} 57^{\prime}$ & 253,321 & $103,188^{*}$ & 2,386 & 13.5 & 0.77 \\
\hline 8. Rio Verde & 715 & $17^{\circ} 47^{\prime}$ & $50^{\circ} 55^{\prime}$ & 194,151 & $14,492 * *$ & 1,775 & 6.8 & 0.96 \\
\hline 9. Ipiranga & 572 & $15^{\circ} 16^{\prime}$ & $49^{\circ} 67^{\prime}$ & 73,027 & $35,565^{\mathrm{ns}}$ & 911 & 20.7 & 0.72 \\
\hline 10. Inhumas & 770 & $16^{\circ} 21^{\prime}$ & $49^{\circ} 29^{\prime}$ & 147,827 & $71,523^{*}$ & 1,862 & 14.4 & 0.72 \\
\hline \multirow[t]{2}{*}{ 11. Santo Antônio de Goiás } & 823 & $16^{\circ} 29^{\prime}$ & $49^{\circ} 18^{\prime}$ & 95,609 & $36,935^{*}$ & 623 & 30.8 & 0.78 \\
\hline & \multicolumn{8}{|c|}{ Dry season in 2009} \\
\hline 12. Inhumas & 770 & $16^{\circ} 21^{\prime}$ & $49^{\circ} 29^{\prime}$ & 112,411 & $181,590^{\mathrm{ns}}$ & 1,539 & 18.6 & 0.52 \\
\hline 13. Ipiranga & 572 & $15^{\circ} 16^{\prime}$ & $49^{\circ} 67^{\prime}$ & 396,169 & $90,494 * *$ & 2,676 & 11.2 & 0.88 \\
\hline \multirow[t]{2}{*}{ 14. Rubiataba } & 632 & $15^{\circ} 09^{\prime}$ & $49^{\circ} 48^{\prime}$ & 425,014 & $81,874 * *$ & 2,795 & 10.2 & 0.90 \\
\hline & \multicolumn{8}{|c|}{ Rainy season in 2009} \\
\hline 15. São Sebastião & 1,036 & $15^{\circ} 56^{\prime}$ & $47^{\circ} 43^{\prime}$ & 166,404 & $99,784^{\text {ns }}$ & 1,723 & 18.3 & 0.63 \\
\hline 16. Santo Antônio de Goiás & 823 & $16^{\circ} 29^{\prime}$ & $49^{\circ} 18^{\prime}$ & 159,411 & $138,425^{\mathrm{ns}}$ & 1,836 & 20.3 & 0.36 \\
\hline \multirow[t]{2}{*}{ 17. Anápolis } & 1,017 & $16^{\circ} 19^{\prime}$ & $48^{\circ} 57^{\prime}$ & 566,822 & $132,592 * *$ & 2,841 & 12.8 & 0.88 \\
\hline & \multicolumn{8}{|c|}{ Dry season in 2010} \\
\hline 18. Santo Antônio de Goiás & 823 & $16^{\circ} 29^{\prime}$ & $49^{\circ} 18^{\prime}$ & 149,932 & $60,764 *$ & 1,632 & 15.1 & 0.77 \\
\hline 19. Nova Veneza & 806 & $16^{\circ} 22^{\prime}$ & $49^{\circ} 19^{\prime}$ & 110,307 & $20,490 * *$ & 1,054 & 13.6 & 0.90 \\
\hline 20. Rubiataba & 632 & $15^{\circ} 09^{\prime}$ & $49^{\circ} 48^{\prime}$ & 30,347 & $12,113^{*}$ & 507 & 21.7 & 0.78 \\
\hline
\end{tabular}

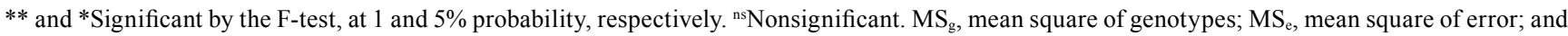
SA, selective accuracy. 
adjust their production system, so that genotypes may express their potential adequately (Desclaux et al., 2008).

Except for the trial in Santo Antônio de Goiás during the rainy season in 2008, all coefficients of variation were below 25\%, as required by Registro Nacional de Cultivares of Ministry of Agriculture (Brasil, 2006). The estimation of selective accuracy (SA), which evaluates the precision of an experiment, revealed that of the 20 trials: 5 presented very high $\mathrm{SA}(\geq 0.90)$, 11 high SA $(\geq 0.7$ and $<0.90), 3$ moderate SA $(\geq 0.50$ and $<0.70)$, and 1 low SA $(<0.50)$, ranked according to Resende \& Duarte (2007). Pereira et al. (2011, 2012), however, found only high or very high SA for common bean grain yield. It should be noted that for some authors SA is considered more appropriate than the coefficient of variation to evaluate experimental accuracy (Cargnelutti Filho \& Storck, 2009).

The mean coefficient of variation of $16.5 \%$ indicated good experimental precision in the environments in the properties of the rural farmers (Table 2). The total average yield of the trials was $1,387 \mathrm{~kg} \mathrm{ha}^{-1}$, similar to the national average (Silva \& Wander, 2013), indicating the potential of cultivars and lines in environments considered unfavorable.

The joint analysis of all sources of variations showed differences in the performance of the studied genotypes, environments, and their interaction (Table 2). A variation of 1.6 and $87.8 \%$ was observed for the source genotypes and environments, respectively, which, according to Yan (2002), is within the expected, i.e., genetic and interaction variations should usually be low and the environmental variations should be above $80 \%$. In the present study, the genotype $x$ environment interaction explained $5.03 \%$ of total variation. This is an indicative of the percentage of participation of each source in the total variation of the character yield, which reinforces the importance of estimating the effects of interaction, in order to enhance the selection process (Yan, 2002).

According to the AMMI model, the interaction was decomposed by independent principal component analysis into 14 main components, of which the first three were responsible for $27.24,25.94$, and $13.07 \%$ of the square sum of the interaction, respectively. The AMMI 3 model was chosen because it associated significance for the axis and no significance for the residue (Table 2).

The CNFC 10721 and CNFC 10733 carioca grain lines and the CNFRX 11996 purple grain line were considered the most stable, according to the WAAS, for the conditions of the family farming system in the state of Goiás (Table 3). The BRS Pitanga and BRS Pontal cultivars and the CNFC 10753 line contributed the most to the interaction with environments due to their highest WAAS values. Pereira et al. (2009a, 2016) used this estimation to identify stable carioca grain genotypes - such as the BRS Estilo and Pérola cultivars - in states of the Midwestern and Northeastern regions of Brazil.

Table 2. Summary of the joint analysis of variance with the decomposition of the sum of squares of the genotype $x$ environment interaction $\left(\mathrm{SS}_{(\mathrm{GxE})}\right)$ for grain yield of common bean (Phaseolus vulgaris) lines and cultivars in 20 environments.

\begin{tabular}{|c|c|c|c|c|c|}
\hline Source of variation & $\mathrm{df}$ & Sum of squares & Mean squares & $\mathrm{R}^{2}(\%)$ & $\mathrm{E}(\%)$ \\
\hline Environments (E) & 19 & $576,784,938$ & $30,357,102 * *$ & 87.80 & - \\
\hline Replicate (environments) & 40 & $7,139,731$ & $178,493 * *$ & 1.08 & - \\
\hline Genotypes (G) & 14 & $10,208,892$ & $729,206^{* *}$ & 1.60 & - \\
\hline $\mathrm{E} \times \mathrm{G}$ & 266 & $33,031,242$ & $124,177^{* *}$ & 5.03 & - \\
\hline \multirow[t]{2}{*}{ Error } & 546 & $29,135,616$ & 53,361 & - & - \\
\hline & \multicolumn{5}{|c|}{ AMMI model } \\
\hline IPCA1 & 32 & $9,028,128$ & $282,129 * *$ & - & 27.24 \\
\hline IPCA2 & 30 & $8,597,730$ & $286,591 * *$ & - & 25.94 \\
\hline IPCA3 & 28 & $4,333,700$ & $154,775 * *$ & - & 13.07 \\
\hline Deviation & 176 & & $63,513^{\text {ns }}$ & - & - \\
\hline Coefficient of variation (\%) & 16.5 & & & & \\
\hline General mean $\left(\mathrm{kg} \mathrm{ha}^{-1}\right)$ & 1,387 & & & & \\
\hline
\end{tabular}

Pesq. agropec. bras., Brasília, v.53, n.2, p.189-196, Feb. 2018

DOI: 10.1590/S0100-204X2018000200007 
When associating stability with productivity, the most promising lines for the evaluated conditions, using the WAASP, were CNFC 10729, CNFC 10753, and CNFRX 10241 (Table 3). This strategy was also adopted by Torga et al. (2016) and Pontes Júnior et al. (2016) to mitigate the problem of more stable lines or cultivars not being among the genotypes with higher yield.

The lines considered promising were the same in the methodology of Lin \& Binns (1988) modified by Oliveira et al. (2006) and in the WAASP, both in the overall analysis and in the favorable and unfavorable environments. The only difference was their ranking in relation to the studied environments (Table 4). This shows the potential of the common bean lines from the breeding program of Embrapa Arroz e Feijão for the conditions of the family farming system, in which the species is usually grown in marginal areas; identifying these genotypes may make the crop more competitive in these sites (Sena et al., 2008). In both methods, the genotypes with the lowest average yield values also presented low stability and, therefore, a larger contribution to the interaction. The similarities between the two methodologies in identifying the best and the worst genotypes suggest that only one is enough to aid the breeder in the selection process.
The genotype with ideal behavior proposed by Cruz et al. (1989) was not found among the studied cultivars and lines, or in the works of Oliveira et al. (2006) and Pereira et al. (2009a). According to Cruz et al. (1989), this genotype must present high average yield, responsiveness to environmental improvement $\left(\beta_{1 \mathrm{i}}+\beta_{2 \mathrm{i}}>1\right)$, adaptability to unfavorable environments $\left(\beta_{1 \mathrm{i}}<1\right)$, and high (nonsignificant $\sigma_{\mathrm{di}}^{2}$ ) or tolerable (significant $\sigma_{\text {di }}^{2}$ and $\mathrm{R}^{2}$ over $80 \%$ ) predictability.

Only the BRS Requinte cultivar showed adaptability to unfavorable environments and high predictability, but was not responsive to the improvement of the environments (Table 5). Although its grain yield did not exceed the overall average, this cultivar has potential for low-technology environments due to its excellent grain quality, with slow darkening and resistance to important crop diseases (Faria et al., 2004), making it an option for the family farming system of the state of Goiás. The CNFC 10753 carioca grain line, in turn, was responsive to the improvement of the environments and showed an average yield above the overall average, high $\mathrm{R}^{2}$ value, and high predictability, being promising for environments with greater use of inputs, but did not present specific adaptability to unfavorable environments. The BRS Cometa cultivar showed responsiveness to environmental improvement and high predictability of behavior; however, it did

Table 3. Means and values of the main components (IPCA) significant for each genotype of common bean (Phaseolus vulgaris) evaluated in the state of Goiás, Brazil, used to calculate the weighted average of absolute scores (WAAS) and the weighted average of absolute scores and productivity (WAASP), as well as the classification of the genotypes for stability by the additive main effects and multiplicative interaction (AMMI) methodology $\mathrm{y}^{(1)}$.

\begin{tabular}{|c|c|c|c|c|c|c|c|c|}
\hline Genotype & Yield $\left(\mathrm{kg} \mathrm{ha}^{-1}\right)$ & IPCA1 & IPCA2 & IPCA3 & WAAS & $\mathrm{C}$ & WAASP & $\mathrm{C}$ \\
\hline CNFC 10753 & $1,580 \mathrm{a}$ & 29.16 & 1.05 & -0.55 & 12.6 & 13 & 96.1 & 2 \\
\hline CNFC 10729 & $1,579 \mathrm{a}$ & 12.14 & -7.46 & 2.10 & 8.4 & 8 & 97.8 & 1 \\
\hline CNFRX 10241 & $1,513 \mathrm{a}$ & 7.42 & 4.10 & 20.06 & 8.6 & 10 & 95.2 & 3 \\
\hline BRS Vereda & $1,450 \mathrm{~b}$ & -4.22 & -7.14 & 8.31 & 6.2 & 6 & 93.7 & 4 \\
\hline CNFC 10713 & $1,440 \mathrm{~b}$ & -1.53 & -10.95 & -11.73 & 7.2 & 7 & 93.1 & 6 \\
\hline CNFC 10721 & $1,407 \mathrm{~b}$ & -0.70 & -5.20 & 4.13 & 3.1 & 1 & 93.5 & 5 \\
\hline BRS Pontal & $1,405 \mathrm{~b}$ & -10.08 & 15.92 & 11.38 & 12.6 & 14 & 89.5 & 10 \\
\hline CNFC 10758 & $1,371 \mathrm{c}$ & -0.38 & -12.24 & -2.79 & 5.5 & 5 & 91.1 & 7 \\
\hline BRS Cometa & $1,347 \mathrm{c}$ & 4.83 & 20.49 & -5.30 & 11.1 & 12 & 87.8 & 11 \\
\hline CNFC 10757 & $1,338 \mathrm{c}$ & -10.54 & -1.76 & -0.93 & 5.2 & 4 & 90.1 & 8 \\
\hline CNFC 10733 & $1,336 \mathrm{c}$ & 2.45 & 5.69 & -7.93 & 4.8 & 3 & 90.1 & 9 \\
\hline CNFRS 11997 & $1,299 \mathrm{c}$ & -6.89 & -18.43 & -3.19 & 10.7 & 11 & 86.3 & 13 \\
\hline CNFRX 11996 & $1,259 \mathrm{~d}$ & 4.64 & 2.91 & -8.05 & 4.6 & 2 & 87.2 & 12 \\
\hline BRS Requinte & $1,239 \mathrm{~d}$ & -15.23 & -1.47 & 8.29 & 8.5 & 9 & 85.06 & 14 \\
\hline BRS Pitanga & $1,235 \mathrm{~d}$ & -11.04 & 14.49 & -13.81 & 12.9 & 15 & 82.9 & 15 \\
\hline
\end{tabular}

${ }^{(1)}$ Means followed by equal letters do not differ by Scott-Knott's test, at $10 \%$ probability. C, classification of genotypes for stability. 
not stand out among the most productive ones, being ranked in the third group of means.

The CNFRX 11996, 'BRS Requinte', 'BRS Pitanga', CNFC 10753, CNFC 10729, CNFC 11997, and 'BRS Vereda' genotypes are located at extreme points of the polygon in the graphical analysis by the GGE biplot (Figure 1). It was possible to identify the formation of three mega-environments, i.e., different cultivars and lines adapted to different groups of environments. The CNFC 10753 and CNFRX 10241 lines present wide adaptation in eight of the evaluated environments, located at the right of the center of the biplot, which shows higher performance, being among the most productive lines (Table 3). This result is in alignment with those of the methodology of Linn \& Binns (1988) and of the WAASP.

However, the BRS Pitanga and BRS Requinte cultivars and the CNFRX 11996 line presented performance below the overall average, since they were located to the left of the graph. The same result was observed for the environments; however, it was not possible to identify those with lower performance. The BRS Vereda cultivar and the CNFC 10729 and CNFC 10713 lines were also considered positively associated (adapted) to eight environments, and CNFC 10713 is among the most stable, since it is close to the center of the biplot. Also among the most stable genotypes are: CNFC 10733, CNFX 10241, CNFC 10758, and 'BRS
Pontal'. In the other three environments, 'BRS Pontal' and CNFC 10721 were the most adapted.

In relation to the recommendation of cultivars, that is, of materials already released and available on the market, 'BRS Vereda' from the rose group of special beans was the most stable and adapted, according to the WAASP and to Lin \& Binns (1988), both for overall analysis and favorable environments. The cultivar is an option for short-term recommendation due to its resistance to anthracnose, rust, angular spot, and common mosaic virus (Otsubo et al., 2005). For unfavorable environments, 'BRS Pontal' (carioca group) showed satisfactory performance for family farming with more restricted use of technologies. BRS Pitanga, from the purple group of special beans, was the cultivar with the lowest values for stability and adaptability, according to AMMI (WAASP), Lin \& Binns (1988), and GGE biplot graphical analysis. This is a cultivar that presents good cooking quality, as well as resistance to diseases (Rava et al., 2005).

In general, the CNFC 10729, CNFC 10753, and CNFC 10241 lines presented superior potential compared with the five evaluated cultivars. It should also be pointed out that these lines and cultivars can be used as parents in breeding programs, in order to obtain segregating populations with potential for selection.

Table 4. Estimates of parameters of phenotypic $\left(\mathrm{P}_{\mathrm{i}}\right)$ stability and adaptability decomposed into favorable $\left(\mathrm{P}_{\text {if }}\right)$ and unfavorable environments $\left(\mathrm{P}_{\mathrm{id}}\right)$, according to the method of Lin \& Binns (1988) modified by Oliveira et al. (2006), for 15 common bean (Phaseolus vulgaris) genotypes evaluated in 20 environments in the state of Goiás, Brazil, from 2007 to 2010.

\begin{tabular}{llllc}
\hline Genotype & \multicolumn{1}{c}{$P_{\mathrm{i}}$} & Genotype & $\mathrm{P}_{\text {if }}$ & Genotype \\
\hline CNFC 10729 & 28,917 & CNFC 10753 & 38,526 & CNFRX 10241 \\
CNFC 10753 & 31,511 & CNFC 10729 & 39,029 & CNFC 10729 \\
CNFRX 10241 & 55,661 & CNFRX 10241 & 92,655 & CNFC 10753 \\
BRS Vereda & 81,065 & BRS Vereda & 132,823 & BRS Pontal \\
CNFC 10713 & 91,048 & CNFC 10721 & 140,527 & BRS Vereda \\
CNFC 10721 & 91,507 & CNFC 10713 & 148,627 & CNFC 10713 \\
BRS Pontal & 113,958 & CNFC 10758 & 185,026 & CNFC 10757 \\
CNFC 10758 & 113,967 & BRS Pontal & 202,800 & CNFC 10721 \\
BRS Cometa & 126,336 & BRS Cometa & 207,170 & CNFC 10758 \\
CNFC 10733 & 126,363 & CNFC 10733 & 208,212 & CNFC 10733 \\
CNFC 10757 & 136,730 & CNFC 10757 & 232,133 & BRS Cometa \\
CNFRX 11996 & 160,049 & CNFRX 11996 & 235,578 & BRS Requinte \\
CNFRS 11997 & 164,236 & CNFRS 11997 & 268,262 & 42,907 \\
BRS Requinte & 195,542 & BRS Requinte & 340,017 & BRS Pitanga \\
BRS Pitanga & 207,293 & BRS Pitanga & 354,573 & CNFRS 11997 \\
\hline
\end{tabular}

Pesq. agropec. bras., Brasília, v.53, n.2, p.189-196, Feb. 2018

DOI: 10.1590/S0100-204X2018000200007 
Table 5. Estimates of the following parameters of phenotypic stability and adaptability: average yield $\left(\hat{\beta}_{0 \mathrm{i}}\right)$, regression coefficients $\left(\hat{\beta}_{1 \mathrm{i}}\right.$ and $\hat{\beta}_{1 \mathrm{i}}+\hat{\beta}_{2 \mathrm{i}}$ ), and regression deviation $\left(\hat{\sigma}_{\text {di }}^{2}\right.$ ), according to the method of Cruz et al. (1989), for 15 common bean (Phaseolus vulgaris) genotypes evaluated in 20 environments in the state of Goiás, Brazil, from 2007 to $2010^{(1)}$.

\begin{tabular}{lccccc}
\hline Genotype & $\hat{\beta}_{0 \mathrm{i}}{ }^{(2)}$ & $\hat{\beta}_{1 \mathrm{i}}$ & $\hat{\beta}_{1 \mathrm{i}}+\hat{\beta}_{2 \mathrm{i}}$ & $\hat{\sigma}_{\mathrm{di}}^{2}\left(10^{3}\right)$ & $\mathrm{R}^{2}(\%)$ \\
\hline CNFC 10753 & $1,580 \mathrm{a}$ & $1.19^{* *}$ & $1.57^{* *}$ & $75.74^{\text {ns }}$ & 97.9 \\
CNFC 10729 & $1,579 \mathrm{a}$ & $1.12^{\text {ns }}$ & $1.11^{\text {ns }}$ & $84.84^{\text {ns }}$ & 97.2 \\
CNFRX 10241 & $1,513 \mathrm{a}$ & $1.07^{\text {ns }}$ & $1.16^{\text {ns }}$ & $124.52^{\text {ns }}$ & 95.6 \\
BRS Vereda & $1,450 \mathrm{~b}$ & $1.07^{\text {ns }}$ & $0.86^{\text {ns }}$ & $82.67^{\text {ns }}$ & 96.8 \\
CNFC 10713 & $1,440 \mathrm{~b}$ & $1.02^{\text {ns }}$ & $0.82^{\text {ns }}$ & $87.47^{\text {ns }}$ & 96.3 \\
CNFC 10721 & $1,407 \mathrm{~b}$ & $1.05^{\text {ns }}$ & $0.98^{\text {ns }}$ & $70.41^{\text {ns }}$ & 97.2 \\
BRS Pontal & $1,405 \mathrm{~b}$ & $0.96^{\text {ns }}$ & $0.94^{\text {ns }}$ & $155.73^{* *}$ & 93.2 \\
CNFC 10758 & $1,371 \mathrm{c}$ & $0.99^{\text {ns }}$ & $0.94^{\text {ns }}$ & $97.59^{\text {ns }}$ & 95.8 \\
BRS Cometa & $1,347 \mathrm{c}$ & $0.98^{\text {ns }}$ & $1.36^{* *}$ & $119.55^{\text {ns }}$ & 95.6 \\
CNFC 10757 & $1,338 \mathrm{c}$ & $0.94^{\text {ns }}$ & $0.77^{\text {ns }}$ & $42.91^{\text {ns }}$ & 97.8 \\
CNFC 10733 & $1,336 \mathrm{c}$ & $0.95^{\text {ns }}$ & $1.15^{\text {ns }}$ & $79.79^{\text {ns }}$ & 96.6 \\
CNFRS 11997 & $1,299 \mathrm{c}$ & $0.97^{\text {ns }}$ & $0.71^{\text {ns }}$ & $111.07^{\text {ns }}$ & 94.7 \\
CNFRX 11996 & $1,259 \mathrm{~d}$ & $0.96^{\text {ns }}$ & $1.07^{\text {ns }}$ & $62.25^{\text {ns }}$ & 97.3 \\
BRS Requinte & $1,239 \mathrm{~d}$ & $0.85^{*}$ & $0.81^{\text {ns }}$ & $72.59^{\text {ns }}$ & 95.8 \\
BRS Pitanga & $1,235 \mathrm{~d}$ & $0.88^{\text {ns }}$ & $0.76^{\text {ns }}$ & $133.65^{\text {ns }}$ & 92.8 \\
\hline
\end{tabular}

${ }^{(1)}$ Means followed by equal letters do not differ by Scott-Knott's test, at $10 \%$ probability. ${ }^{(2)} \mathrm{H}_{0}: \beta_{1 \mathrm{i}}=1 ; \mathrm{H}_{0}: \beta_{1 \mathrm{i}}+\beta_{2 \mathrm{i}}=1 . \mathrm{R}^{2}$, coefficient of determination. $* *$ and $*$ Significant by the t-test, at 1 and $5 \%$ probability, respectively.

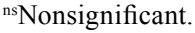

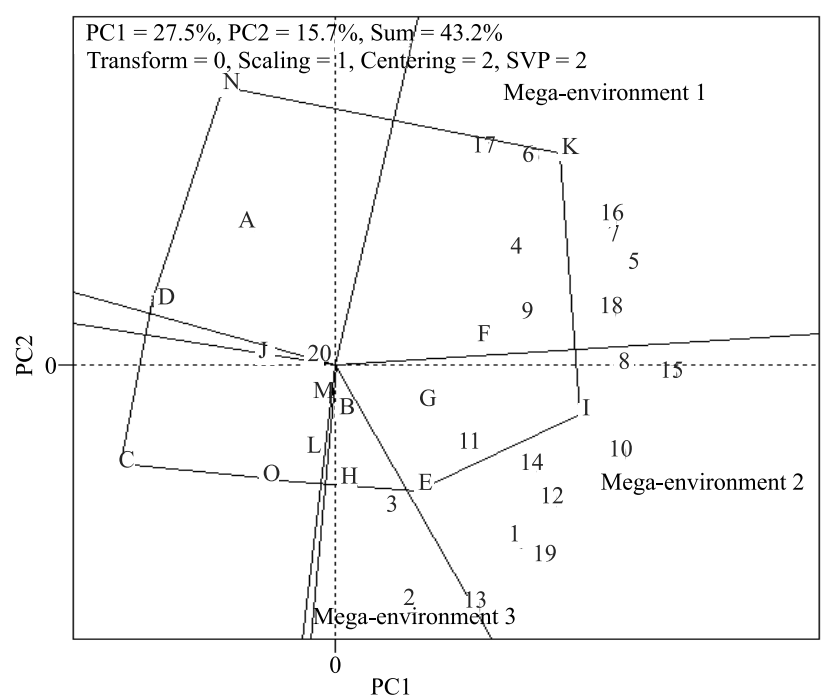

Figure 1. GGE biplot methodology based on the principal components 1 and 2 (PC1 and PC2) for grain yield ( $\left.\mathrm{kg} \mathrm{ha}^{-1}\right)$ of 15 common bean (Phaseolus vulgaris) lines and cultivars evaluated in 20 environments (Table 1) in the state of Goiás, Brazil. A, BRS Cometa; B, BRS Pontal; C, BRS Requinte; D, BRS Pitanga; E, BRS Vereda; F, CNFRX 10241; G, CNFC 10713; H, CNFC 10721; I, CNFC 10729; J, CNFC 10733; K, CNFC 10753; L, CNFC 10757; M, CNFC 10758; N, CNFRX 11996; and O, CNFRS 11997. SVP, $x$.

\section{Conclusions}

1. The productive performance of common bean (Phaseolus vulgaris) lines and cultivars is affected by the genotype $\mathrm{x}$ environment interaction.

2. The BRS Vereda cultivar from the rose group of special beans is the most stable and adapted to favorable environments.

3. The BRS Pontal cultivar shows satisfactory performance for the conditions of the family farming system where the use of technologies is more restricted.

4. The CNFC 10729, CNFC 10753, and CNFC 10241 lines stand out because they present higher productive potential than the BRS Cometa, BRS Pontal, BRS Requinte, BRS Pitanga, and BRS Vereda cultivars.

\section{References}

BRASIL. Ministério da Agricultura, Pecuária e Abastecimento. Instrução Normativa $n^{\circ} 25$, de 23 de maio de 2006. Anexo I. Requisitos mínimos para determinação do valor de cultivo e uso de feijão (Phaseolus vulgaris) para a inscrição no registro nacional de cultivares - RNC. Diário Oficial da União, 19 jun. 2006. Seção 1, p.17. Available at: <http:// pesquisa.in.gov.br/imprensa/jsp/visualiza/index.jsp?data= 19/06/2006\&jornal $=1 \&$ pagina $=17 \&$ totalArquivos $=80>$. Accessed on: Oct. 192017.

BUCHEYEKI, T.L.; MMBAGA, T.E. On-farm evaluation of beans varieties for adaptation and adoption in Kigoma Region in Tanzania. ISRN Agronomy, v.2013, article 436064, p.1-5, 2013. DOI: $10.1155 / 2013 / 436064$

CARGNELUTTI FILHO, A.; STORCK, L. Medidas do grau de precisão experimental em ensaios de competição de cultivares de milho. Pesquisa Agropecuária Brasileira, v.44, p.111-117, 2009. DOI: 10.1590/S0100-204X2009000200001.

CRUZ, C.D.; TORRES, R.A.; VENCOVSKY, R. An alternative approach to the stability analysis proposed by Silva and Barreto. Revista Brasileira de Genética, v.12, p.567-580, 1989.

DESCLAUX, D.; NOLOT, J.M.; CHIFFOLEAU, Y.; GOZÉ, E.; LECLERC, C. Changes in the concept of genotype $\times$ environment interactions to fit agriculture diversification and decentralized participatory plant breeding: pluridisciplinary point of view. Euphytica, v.163, p.533-546, 2008. DOI: 10.1007/s10681-008-9717-2.

DUARTE, J.B.; VENCOVSKY, R. Interação genótipos $\mathbf{x}$ ambientes: uma introdução à análise "AMMI". Ribeirão Preto: Sociedade Brasileira de Genética, 1999. 60p. (Monografia, no 9).

FARIA, L.C. de; COSTA, J.G.C. da; RAVA, C.A.; DEL PELOSO, M.J.; MELO, L.C.; CARNEIRO, G.E. de S.; SOARES, D.M.; Diaz, J.L.C.; ABREU, A. de F.B.; FARIA, J.C. de; SARTORATO, A.; SILVA, H.T. da; BASSINELL, P.Z.; ZIMMERMANN, F.J.P. 'BRS Requinte': new common bean Carioca cultivar with delayed grain darkness. Crop Breeding and Applied Biotechnology, v.4, p.366-368, 2004. DOI: 10.12702/1984-7033.v04n03a19. 
FEIJÃO. Dados de conjuntura da produção de feijão comum (Phaseolus vulgaris L.) e caupi (Vigna unguiculata L. Walp) no Brasil: 1985-2014. Available at: <http://www.cnpaf.embrapa.br/ socioeconomia/index.htm>. Accessed on: Jan. 152016.

LIN, C.S.; BINNS, M.R. A superiority measure of cultivar performance for cultivar $\mathrm{x}$ location data. Canadian Journal of Plant Science, v.68, p.193-198, 1988. DOI: 10.4141/cjps88-018.

MALOSETTI, M.; RIBAUT, J.-M.; EEUWIJK, F.A. van. The statistical analysis of multi-environment data: modeling genotypeby-environment interaction and its genetic basis. Frontiers in Physiology, v.4, article 44, 2013. DOI: 10.3389/fphys.2013.00044.

MELO, L.C.; MELO, P.G.S.; FARIA, L.C. de; DÍAZ, J.L.C.; DEL PELOSO, M.J.; RAVA, C.A.; COSTA, J.G.C. da. Interação com ambientes e estabilidade de genótipos de feijoeiro-comum na Região Centro-Sul do Brasil. Pesquisa Agropecuária Brasileira, v.42, p.715-723, 2007. DOI: 10.1590/S0100-204X2007000500015.

OLIVEIRA, G.V.; CARNEIRO, P.C.S.; CARNEIRO, J.E. de S.; CRUZ, C.D. Adaptabilidade e estabilidade de linhagens de feijão comum em Minas Gerais. Pesquisa Agropecuária Brasileira, v.41, p.257-265, 2006. DOI: 10.1590/S0100-204X2006000200010.

OTSUBO, A.A.; OTUBO, S.T.; ZUFFO, N.L.; DEL PELOSO, M.J.; FARIA, L.C. de; MELO, L.C.; COSTA, J.G.C. da; RAVA, C.A.; CARNEIRO, G.E. de S.; SOARES, D.M.; DIAZ, J.L.C.; FARIA, J.C. de; SARTORATO, A.; MERCANTE, F.M. BRS Vereda: nova cultivar de feijão do grupo Rosinha para Mato Grosso do Sul. Dourados: Embrapa Agropecuária Oeste, 2005. 4p. (Embrapa Agropecuária Oeste. Comunicado técnico 113).

PEREIRA, H.S.; ALMEIDA, V.M. de; MELO, L.C.; WENDLAND, A.; FARIA, L.C. de; DEL PELOSO, M.J.; MAGALDI, M.C. de S. Influência do ambiente em cultivares de feijoeiro-comum em cerrado com baixa altitude. Bragantia, v.71, p.165-172, 2012. DOI: 10.1590/S0006-87052012005000024.

PEREIRA, H.S.; ALVARES, R.C.; MELO, L.C.; COSTA, A.F. da; CARVALHO, H.W.L. de; FARIA, L.C. de; SOUZA, T.L.P.O. de. Genotype by environment interaction of "carioca" seeded common bean advanced lines in northeastern Brazil. Semina: Ciências Agrárias, v.37, p.1745-1756, 2016. DOI: 10.5433/1679-0359.2016v37n4p1745.

PEREIRA, H.S.; MELO, L.C.; DEL PELOSO, M.J.; FARIA, L.C. de; WENDLAND, A. Complex interaction between genotypes and growing seasons of carioca common bean in Goiás/Distrito Federal. Crop Breeding and Applied Biotechnology, v.11, p.207-215, 2011. DOI: 10.1590/S1984-70332011000300002.

PEREIRA, H.S.; MELO, L.C.; FARIA, L.C. de; DEL PELOSO, M.J.; COSTA, J.G.C. da; RAVA, C.A.; WENDLAND, A. Adaptabilidade e estabilidade de genótipos de feijoeiro-comum com grãos tipo carioca na Região Central do Brasil. Pesquisa Agropecuária Brasileira, v.44, p.29-37, 2009a. DOI: 10.1590/ S0100-204X2009000100005.

PEREIRA, H.S.; MELO, L.C.; FARIA, L.C.; DÍAZ, J.L.C.; DEL PELOSO, M.J.; COSTA, G.C.; WENDLAND, A. Stability and adaptability of carioca common bean genotypes in states of the central South Region of Brazil. Crop Breeding and Applied Biotechnology, v.9, p.181-188, 2009b. DOI: 10.12702/1984-7033. v09n02a11.

PONTES JÚNIOR, V.A.; MELO, P.G.S.; PEREIRA, H.S.; MELO, L.C. Genetic potential of common bean progenies obtained by different breeding methods evaluated in various environments. Genetics and Molecular Research, v.15, p.1-12, 2016. DOI: 10.4238/gmr.15038622.

RAVA, C.A.; FARIA, L.C. de; COSTA, J.G.C. da; DEL PELOSO, M.J.; MELO, L.C.; DIAZ, J.L.C.; FARIA, J.C. de; SILVA, H.T. da; SARTORATO, A.; BASSINELLO, P.Z.; ZIMMERMANN, F.J.P. 'BRS Pitanga': new dry bean variety of the small purple group. Crop Breeding and Applied Biotechnology, v.5, p.475-476, 2005. DOI: 10.12702/1984-7033.v05n04a15.

RESENDE, M.D.V. de; DUARTE, J.B. Precisão e controle de qualidade em experimentos de avaliação de cultivares. Pesquisa Agropecuária Tropical, v.37, p.182-194, 2007.

SENA, M.R.; ABREU, A. de F.B.; RAMALHO, M.A.P.; BRUZI, A.T. Envolvimento de agricultores no processo seletivo de novas linhagens de feijoeiro. Ciência e Agrotecnologia, v.32, p.407$412,2008$.

SILVA, O.F. da; WANDER, A.E. O feijão-comum no Brasil: passado, presente e futuro. Santo Antônio de Goiás: Embrapa Arroz e Feijão, 2013. 63p. (Embrapa Arroz e Feijão. Documentos, 287).

TORGA, P.P.; MELO, P.G.S.; PEREIRA, H.S.; FARIA, L.C. de; DEL PELOSO, M.J.; MELO, L.C. Decomposition of the interaction of common black bean group genotypes with the environment. Agricultural Sciences, v.4, p.683-688, 2013a. DOI: 10.4236/as.2013.412092.

TORGA, P.P.; MELO, P.G.S.; PEREIRA, H.S.; FARIA, L.C. de; DEL PELOSO, M.J.; MELO, L.C. Interaction of common beans cultivars of the black group with years, locations and sowing seasons. Euphytica, v.189, p.239-248, 2013b. DOI: 10.1007/ s10681-012-0793-y.

TORGA, P.P.; MELO, P.G.S.; PEREIRA, H.S.; FARIA, L.C.; MELO, L.C. Genetic potential of black bean genotypes with predictable behaviors in multienvironment trials. Genetics and Molecular Research, v.15, p.1-13, 2016. DOI: 10.4238/ gmr15049029.

YAN, W. GGEbiplot: a Windows application for graphical analysis of multienvironment trial data and other types of twoway data. Agronomy Journal, v.93, p.1111-1118, 2001. DOI: 10.2134/agronj2001.9351111x.

YAN, W. Singular-value partitioning in biplot analysis of multienvironment trial data. Agronomy Journal, v.94, p.990996, 2002. DOI: 10.2134/agronj2002.0990.

YAN, W.; TINKER, N.A. An integrated biplot analysis system for displaying, interpreting, and exploring genotype $\mathrm{X}$ environment interactions. Crop Science, v.45, p.1004-1016, 2005. DOI: 10.2135/ cropsci2004.0076.

Received on July 4, 2016 and accepted on May 22, 2017

Pesq. agropec. bras., Brasília, v.53, n.2, p.189-196, Feb. 2018

DOI: 10.1590/S0100-204X2018000200007 